\title{
Structure and adaptation of the fauna in the black zone (littoral fringe) along rocky shores in northern Europe
}

\author{
Inge Kronberg
}

Zoologisches Institut der Christian-Albrechts-Universität, Abteilung Marine Ökologie und Systematik, Olshausenstraße, D-2300 Kiel, Federal Republic of Germany

\begin{abstract}
The black zone within the littoral fringe of world-wide rocky shores is overgrown with lichens (Lichina pygmaea, Verrucaria maura), and blue-green algae. The zone is inhabited by a few coenophil animals: Hyadesia fusca (Acari), Telmatogeton japonicus (Chironomidae), Mniobia symbiotica (Rotatoria), Echiniscoides sigismundi (Tardigrada), and several aquatic or terrestrial intruders (Nematoda, Littorina, Copepoda-Harpacticoidea, Ligia, Collembola, terrestrial mites and insects). The main adaptation of foundation species lies in their ability to reduce metabolism by anhydrobiosis or anaerobosis and to survive unfavourable circumstances in quiescence. Faunal structure is influenced by unpredictably changing abiotic factors such as moisture, salinity, temperature and eutrophication, which influence quantitative rather than qualitative aspects
\end{abstract}

\section{INTRODUCTION}

The boundary zone between sea and land along rocky shores is an environment characterized by abrupt change from marine to terrestrial conditions: salinity, light, and temperature alter gradually; submersion and emersion alter periodically and induce the development of a characteristic littoral zonation.

The shore edge above the high water mark is blackened by an overgrowth of blue-green algae and lichens and called the 'black zone' (Stephenson \& Stephenson 1972). The black zone marks the margin between eulittoral and supralittoral. Here, living conditions are characterized by unpredictable changes in abiotic factors: spring tide and wave spray moisten this zone without clear periodicity and involve mechanical stress. Insolation leads to heating and evaporation, and hence tends to increase salinity; rain and dew lead to moistening with freshwater. Thus the black zone is an extreme environment with pronounced variations in moisture, salinity, temperature, light, and wave exposure.

The black zone is a common feature along most rocky shores including artificial shorelines (Stephenson \& Stephenson 1972). Even in the Antarctic, littoral cyanophyte associations are found in the littoral fringe (Broady 1981).
The black zone consists of 3 different plant associations: (1) Cyanophyta (Calothrix, Plectonema, Gloeocapsa, Chroococcus etc.); (2) Lichina pygmaea Lightf. (Lecanorales, Lichenes); (3) Verrucaria maura Wahlenberg (Verrucariales, Lichenes).

The faunal part of the community remains practically unknown; only species of Littorina, Ligia and Chironomidae have been recorded (Southward 1958, Hedgpeth 1957, Stephenson \& Stephenson 1972). The flora has been investigated by Lindstedt (1943), Umezaki (1961) and Little (1973).

The encrusting lichen Verrucaria maura grows preferentially along dry and wave-exposed shores. If crevices are available, they are inhabited by a terrestrial fauna composed of Nanorchestes amphibius and Bdella septemtrionalis (Acarina), Anurida maritima (Collembola), Strigamia maritima (Chilopoda), Petrobius brevistylis (Archaeognatha), and by aquatic forms such as Ligia oceanica (Isopoda) and Littorina neritoides (Gastropoda). Small shrub-like lichens Lichina pygmaea grow in moister sites at the barnacle line, and are inhabited by thalassogen species, such as the isopod Campecopea hirsuta or the molluscs Lasaea rubra, Mytilus edulis (juvenile), Littorina neritoides, $L$. saxatilis, the mites Hyadesia fusca, Ameronothrus spp. and Limoniidae instars (Geranomyia unicolor).

Cyanophytes prefer sheltered shores with wet 
conditions and show a high tolerance to freshwater influence, although they are replaced by mosses in pure freshwater sites. The fauna is composed of a few aquatic animals: Hyadesia fusca (Acarina), Mniobia symbiotica (Rotatoria), Telmatogeton japonicus (Chironomidae), Echiniscoides sigismundi (Tardigrada), Littorina saxatilis (Gastropoda), and several eulittoral and terrestrial intruders.

The black zone is therefore actually an intermediary between sea and land: the Verrucaria maura association belongs to the supralittoral, while cyanophytes and Lichina pygmaea belong, strictly speaking, to the littoral. According to Lewis (1964), the black zone can be attributed to the littoral fringe (Fig. 1).

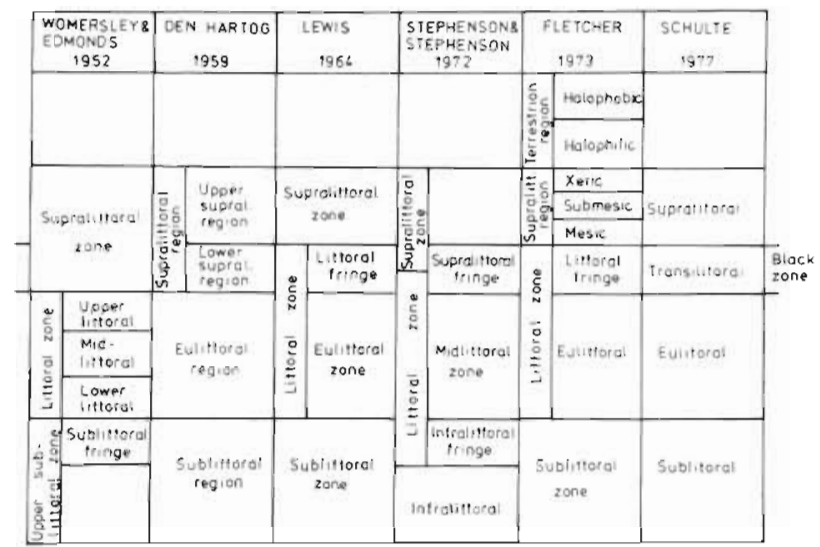

Fig. 1. Comparison of different littoral schemata (adapted from Hedgpeth 1957)

Littoral cyanophytes have been known since the Precambrian (Laporte 1968, Remane 1979) and have continuously provided a potential habitat for animal colonization. The inhabiting fauna, however, consists of few species with high densities, and special adaptations are rare. This is a community structure regarded typical for extreme environments (Thienemann 1939). The present paper investigates the structure and stability of this low diversity community and the influences of salinity, moisture, eutrophication and biotic factors. It also illustrates how animals have adapted to abiotic factors with respect to protection, locomotion, reproduction, development and ingestion.

\section{MATERIALS AND METHODS}

Sampling. Samples were obtained by scraping the rock surface with a knife. For quantitative analysis, 10 square sampling units of 10 or $20 \mathrm{~cm}^{2}$ each, taken at random, formed 1 sample. Samples were stored at $-18^{\circ} \mathrm{C}$ until analysis or were fixed with $4 \%$ formaldehyde. Faunal inhabitants of the overgrowth were studied with a stereomicroscope. Representiveness of samples was tested using similarity area curves which assigned a minimal area of $100 \mathrm{~cm}^{2}$ to include 74 to $100 \%$ of the species and an accuracy of $\pm 10 \%$ for abundance data. Only in seasons when few animals are present were $200 \mathrm{~cm}^{2}$ samples necessary in order to obtain the same degree of accuracy (Kronberg 1987).

Sampling stations were situated mainly in the Baltic Sea and along the Kiel Canal (F.R. Germany). Qualitative samples were taken near Kristineberg (Sweden), Herdla (Norway), Penzance (Cornwall, UK). Sherkin Island (Ireland), and Helgoland (F.R. Germany). Quantitative samples were taken at the following sites:

(a) Two adjacent stations along the Kiel Canal (Landwehr, salinity $8.2 \%$ ) were checked twice a month in 1979. One of the stations had a slope of $10^{\circ}$, the other of $45^{\circ}$. Six units of $10 \mathrm{~cm}^{2}$ made up 1 sample which proved representative for the 3 dominant species. The width of the black zone was recorded and compared with watermarks in the Holtenau canal office. The samples were used to investigate the influence of moisture and exposition.

(b) Two stations at Friedrichsort (Kiel Bight, slope $35^{\circ}$ ): one was protected from rain influence by a bridge, the other exposed to rain. Twenty samples of $10 \mathrm{~cm}^{2}$ were taken from each station in October 1980. These samples served to investigate the influence of moisture and freshwater The role of insolation was negligible during this season.

(c) Eleven stations along the Kiel Canal (slope 30 to $50^{\circ}$; salinity: at Brunsbüttel, $3.6 \%$; Burg, $3.5 \%$; Hohenhörn, $3.4 \%$; Fischerhütte, $3.2 \%$; Oldenbüttel, $3.0 \%$; Breiholz. 3.6\%; Rendsburg, 5.3\%; Sehestedt, $6.6 \%$; Landwehr, $8.2 \%$; Levensau, $10.4 \%$; Holtenau, $11.9 \%$ ) and in the Kiel Bight (Friedrichsort) $13.4 \%$. Ten sample units of $20 \mathrm{~cm}^{2}$ were taken from each station in September 1979. Salinity was determined by titration (Mohr-Knudsen method). These samples were used to investigate the influence of salinity.

(d) Eight stations in Bülk (Kiel Bight, slope 30 to $50^{\circ}$, salinity $15 \%$ ), located at different distances from the sewage duct at breakwaters. Ten sample units of 10 $\mathrm{cm}^{2}$ were taken monthly from each station from 1980 to 1982. In winter, stations were visited every second or third month because they were only scarcely inhabited. One station was abandoned in 1982 owing to construction work at the duct. Samples were used to investigate the influence of eutrophication.

Ecological parameters were: $Z$ : number of species; $Z_{\mathrm{p}}$ : number of species in sample $p ; Z_{p q}$ : number of species common to samples $p$ and $q_{i} C$ (species density): average number of species per defined area $\left(10 \mathrm{~cm}^{2}\right) ; N$ : number of individuals of all species per sample ${ }_{i} W$ (living density): average number of indi- 
viduals of all species per defined area $\left(10 \mathrm{~cm}^{2}\right) ; A_{i}$ (abundance): average number of individuals of species $i$ per defined area $\left(10 \mathrm{~cm}^{2}\right) ; A_{i p}$ : abundance of species $i$ in sample $p ; D_{i}$ (dominance): percentage of individuals of species $i$ per sample; $M$ : total station number; $m_{j}$ : number of stations containing species $i ; P_{i}$ (presence): number of stations containing species $i$ related to total station number.

Diversity: Rarefaction diversity (Sanders 1968) is a graphical method which estimates the theoretical species number of smaller samples starting out from the whole number of individuals; it is a size-independent method. The steepness of the curve represents the evenness; and the level of saturation indicates the number of species. The original method allows a rough comparison of communities, though it tends to overestimate the interpolated expected number of species (Hurlbert 1971).

Similarity: $0 \leqslant I \leqslant 1$

$$
\begin{aligned}
& \text { Sørensen } \quad I_{\mathrm{S}}=\frac{2 Z_{p q}}{Z_{p}+Z_{q}} \\
& \text { Kulzcynski } I_{\mathrm{K}}=\frac{2 \sum_{i=1}^{Z} \min \left(A_{i p}, A_{i q}\right)}{\sum_{i=1}^{Z}\left(A_{i p}+A_{j q}\right)}
\end{aligned}
$$

Statistics were compiled with SPSS-programs at the Computer Center in Kiel; ecological parameters were calculated by a TURBO PASCAL 4.0 program. To calculate similarity area curves, a FORTRAN program (Weinberg 1978, Kronberg 1987) was used. (Programs are available from the author upon request; please enclose a $5.25^{\prime \prime}$ disk.)

\section{RESULTS AND DISCUSSION}

\section{Faunal composition}

To record the inhabitants of the black zone, cyanophytes and Lichina pygmaea associations in different climatic regions were investigated. The Verrucaria maura association was considered only briefly, as the animals living here do not belong to the phytal, but to the crevice fauna (Kronberg 1983).

A total of 67 species was recorded: 17 Nematoda, 13 Acarina, 11 Insecta and 8 Copepoda-Harpacticoidea; but most of these species were represented by only a few individuals (Table 1).

The most abundant species were Rotatoria (Mniobia symbiotica), Tardigrada (Echiniscoides sigismundi), Acarina (Hyadesia fusca), Collembola (Anurida maritima, Hypogastrura viatica), and Chironomida
(Telmatogeton japonicus). None of the species showed a restriction to the black zone, all live in other biotopes as well. $M$. symbiotica, E. sigismundi, $H$. fusca live in the Enteromorpha zone (Marcus 1927, Otto 1936), in eu- and supralittoral rockpools (H. fusca: Ganning 1970 ); in the barnacle zone ( $E$. sigismundi: Morgan \& King 1976, Kristensen \& Hallas 1980); and in lichens and mosses (M. symbiotica: Remane \& Schlieper 1958 Donner 1965). Campecopea hirsuta (Isopoda) and Lasaed rubra (Bivalvia) not only live in the Lichina pygmaea zone but also between barnacles in the trottoir, in the Mediterranean Enteromorpha zone, and in similarly patterned interstices (Woodward 1851, Wieser 1959, Schuster 1962, Nordsieck 1969). Thus the indigenous species of the black zone are coenophil, but not coenobiont. In the Baltic Sea, H. fusca, $T$. japonicus and $M$. symbiotica are 'foundation species' sensu Dayton (1972), their population dynamics being characteristic of the community.

The black zone is an open biotope accessible to terrestrial, marine, limnic and brackish species, as well as to subterranean and flying animals which find, at least for a short time, adequate conditions here. Some actively enter the black zone; for example, from the eulittoral, Littorina saxatilis and, in the Atlantic region, Patella vulgata which feeds here during dampness. During low water, terrestrial animals enter from the supralittoral for feeding, e.g. Anurida maritima, Hypogastrura viatica, Bdella septemtrionalis, Abrolophus rubipes.

A large number of species appear occasionally in high densities; they are not, however, a permanent part of the community: under extreme conditions they withdraw or die, and then the population must replenish itself from similar environments (Nematoda, Copepoda-Harpacticoidea, Ostracoda).

Typical trespassers searching for crevices are $\mathrm{Pe}$ trobius brevistylis (Insecta), Strigamia maritima (Diplopoda) and Ligia oceanica (Isopoda). From the air, Fucellia spp. and Ephydridae (Insecta) visit the black zone. Several terrestrial (Oribatei) and eulittoral mites (Rhombognatus spp.) as well as Nematoda are seen frequently, but more irregularly, in the black zone. Enchytraeus albidus is a subterranean visitor.

Many species living in the black zone are cosmopolitans, i.e. are present in many climatic regions of the world, both at the species and/or genus level. For example, Telmatogeton remanei from the Baltic Sea turned out to be synonymous to $T$. japonicus from the Pacific Ocean (Kronberg 1986). Echiniscoides sigismundi has been reported from the Baltic Sea, the Mediterranean (Wieser 1959), the Galapagos Islands (McKirdy et al. 1976), the Caribbean and China (Green 1950). This spectrum of species is influenced by several micro- and macroclimatic factors. 
Table 1. Fauna Iist for the black zone in northern Europe. L: Lichina pygmaea association; C: Cyanophyta association. O: eastern coastline of Schleswig-Holstein (FRG); K: Kiel Canal (FRG); W. western coastline of Schleswig-Holstein; S: Sweden (Kristineberg); N: Norway (Herdla); G: UK (Penzance); I: Ireland (Sherkin Island)

\begin{tabular}{|c|c|c|c|c|c|c|c|c|c|}
\hline Assoc. & Taxa & & $\mathrm{O}$ & $\mathrm{K}$ & W & $\mathrm{S}$ & $N$ & $G$ & I \\
\hline \multicolumn{10}{|c|}{ Nematoda } \\
\hline $\mathrm{C}$ & Rhabditis marina Bastian & (Rhabditidae) & $\mathrm{x}$ & - & $\mathrm{x}$ & - & - & - & - \\
\hline $\mathrm{C}$ & Aphelenchoides sp. & (Aphelenchoididae) & - & $\mathrm{x}$ & - & & $\mathrm{x}$ & & - \\
\hline $\mathrm{C}$ & Monhystera parva Bastian & (Monhysteridae) & $\mathrm{x}$ & $\mathrm{x}$ & - & $\mathrm{x}$ & - & - & - \\
\hline C & Monhystera disjuncta Bastian & (Monhysteridae) & $\mathrm{x}$ & $\mathrm{x}$ & - & - & - & - & - \\
\hline $\mathrm{C}$ & Monhystera sp. & (Monhysteridae) & - & - & $\mathrm{x}$ & - & $\mathrm{x}$ & $\mathrm{x}$ & - \\
\hline $\mathrm{C}$ & Gammarinema sp. & (Monhysteridae) & $\mathrm{x}$ & - & - & - & - & - & - \\
\hline $\mathrm{C}$ & $\begin{array}{l}\text { Theristus pertenuis Bresslau \& Stekhoven } \\
\text { in Stekhoven }\end{array}$ & (XYalidae) & $\mathrm{x}$ & $\mathrm{x}$ & - & - & - & - & - \\
\hline $\mathrm{C}$ & Araeolaimus sp. & (Diplopeltidae) & $\mathrm{x}$ & - & - & - & - & - & - \\
\hline $\mathrm{C}$ & Chromadora nudicapitata Bastian & (Chromadoridae) & $\mathrm{x}$ & - & - & - & - & - & - \\
\hline $\mathrm{C}$ & Chromadora macrolaima de Man & (Chromadoridae) & $\mathrm{x}$ & $\mathrm{x}$ & - & - & - & - & - \\
\hline $\mathrm{C}$ & Chromadorina supralitoralis Lorenzen & (Chromadoridae) & - & $\mathrm{x}$ & - & - & - & - & - \\
\hline $\mathrm{C}$ & Dichromadora cephalata Steiner & (Chromadoridae) & - & $\mathrm{x}$ & - & - & - & - & - \\
\hline $\mathrm{C}$ & Plectus sp. & (Plectidae) & - & $x$ & - & $\mathrm{x}$ & $x$ & - & - \\
\hline $\mathrm{C}$ & Anaplectus sp. & (Plectidae) & - & $x$ & - & - & - & - & - \\
\hline $\mathrm{C}$ & Enoplus sp. (brevis or communis) & (Enoplidae) & $\mathrm{x}$ & - & - & - & - & - & - \\
\hline $\mathrm{C}$ & Adoncholaimus fuscus de Man & (Oncholaimidae) & $\mathrm{x}$ & - & - & - & - & - & - \\
\hline $\mathrm{C}$ & Anticoma acuminata Eberth & (Anticomidae) & $\mathrm{x}$ & - & - & - & - & - & - \\
\hline \multicolumn{10}{|c|}{ Rotatoria } \\
\hline $\mathrm{L}, \mathrm{C}$ & Mniobia symbiotica Zelinka & (Bdelloidea) & $\mathrm{x}$ & $\mathrm{x}$ & $\mathrm{x}$ & $\mathrm{x}$ & $\mathrm{x}$ & $x$ & - \\
\hline \multicolumn{10}{|c|}{ Bivalvia } \\
\hline $\mathrm{L}$ & Lasaea rubra Montagu $=L$. adansoni Gmelin & (Leptonidae) & - & - & - & - & - & $\mathrm{x}$ & $\mathrm{x}$ \\
\hline L, C & Mytilus edulis L. (juv.) & (Mytilidae) & $\mathrm{x}$ & - & $\mathrm{x}$ & - & $\mathrm{x}$ & $\mathrm{x}$ & - \\
\hline \multicolumn{10}{|c|}{ Gastropoda } \\
\hline $\mathrm{C}$ & Littorina neritoides L. & (Littorinidae) & & & - & - & - & $\mathrm{x}$ & $x$ \\
\hline $\mathrm{L}, \mathrm{C}$ & Littorina saxatilis Olivi & (Littorinidae) & $\mathrm{x}$ & $\mathrm{x}$ & $x$ & $\mathrm{x}$ & $\mathrm{x}$ & $\mathrm{x}$ & $\mathrm{x}$ \\
\hline $\mathrm{C}$ & Patella vulgata $\mathrm{L}$. & (Patellacea) & - & - & - & - & - & $x$ & $\mathrm{x}$ \\
\hline \multicolumn{10}{|c|}{ Oligochaeta } \\
\hline$L_{1}, C$ & Enchytraeus sp. & (Enchytraeidae) & - & $x$ & - & - & - & - & $\mathrm{x}$ \\
\hline \multicolumn{10}{|c|}{ Tardigrada } \\
\hline $\mathrm{L}, \mathrm{C}$ & Echiniscoides sigismundi Schultze & (Echiniscoidea) & - & - & $\mathrm{x}$ & $x$ & $\mathrm{x}$ & - & - \\
\hline \multicolumn{10}{|c|}{ Ostracoda } \\
\hline C & Cytherura gibba O.F. Müller & (Cytheridae) & - & $\mathrm{x}$ & - & - & - & - & - \\
\hline $\mathrm{C}$ & Cytheromorpha fuscata Brady & (Cytheridae) & $\mathrm{x}$ & - & - & - & - & - & - \\
\hline \multicolumn{10}{|c|}{ Copepoda-Harpacticoidea } \\
\hline $\mathrm{C}$ & Harpacticus gracilis Claus & (Harpacticidae) & $x$ & - & - & - & - & - & - \\
\hline $\mathrm{C}$ & Harpacticus flexus Brady \& Robertson & (Harpacticidae) & $\mathrm{x}$ & - & - & - & $\mathrm{x}$ & - & - \\
\hline C & Leptomesochra sp. & (Ameiridae) & - & - & - & - & $\mathrm{x}$ & - & - \\
\hline $\mathrm{C}$ & Nitocra typica Boeck & (Ameiridae) & - & $\mathrm{x}$ & - & - & - & - & - \\
\hline $\mathrm{C}$ & Heterolaophonte strömi Baird & (Laophontidae) & - & - & - & $\mathrm{x}$ & - & - & - \\
\hline $\mathrm{L}$ & Heterolaophonte sp. & (Laophontidae) & - & - & - & - & - & $x$ & - \\
\hline $\mathrm{C}$ & Tachidius $\mathrm{sp}$ & (Disaccidae) & $\mathrm{x}$ & - & - & - & - & - & - \\
\hline $\mathrm{C}$ & Mesochra rapiens Schmeil & (Canthocamptidae) & - & - & - & - & $\mathrm{x}$ & - & - \\
\hline \multicolumn{10}{|c|}{ Amphipoda } \\
\hline L, C & Orchestia gammarella Pallas & (Talitridae) & $\mathrm{x}$ & - & - & - & - & - & $\mathrm{x}$ \\
\hline \multicolumn{10}{|c|}{ Isopoda } \\
\hline $\mathrm{C}$ & Ligia oceanica Fabr. (juv.) & (Ligiidae) & - & - & $\mathrm{x}$ & $\mathrm{x}$ & $\mathrm{x}$ & $\mathrm{x}$ & $\mathrm{x}$ \\
\hline $\mathrm{L}$ & Campecopea hirsuta Montagu & (Sphaeromatidae) & - & - & - & - & - & $\mathrm{x}$ & $x$ \\
\hline
\end{tabular}


Table 1 (continued)

\begin{tabular}{|c|c|c|c|c|c|c|c|c|c|}
\hline Assoc. & Taxa & & $\mathrm{O}$ & $\mathrm{K}$ & W & $\mathrm{S}$ & $N$ & G & I \\
\hline \multicolumn{10}{|c|}{ Acarina } \\
\hline L, C & Hyadesia fusca Lohmann & (Hyadesidae) & $\mathrm{x}$ & $x$ & $\mathrm{x}$ & $\mathrm{x}$ & $\mathrm{x}$ & $\mathrm{x}$ & - \\
\hline $\mathrm{C}$ & Hermannia nodosa Michael & (Oribatei) & - & - & - & - & - & - & $\mathrm{x}$ \\
\hline $\mathrm{C}$ & Hermannia sp. & (Oribatei) & $\mathrm{x}$ & - & - & - & - & - & - \\
\hline $\mathrm{L}$ & Ameronothrus maculatus Michael & (Oribatei) & - & - & - & - & - & - & $\mathrm{x}$ \\
\hline $\mathrm{L}$ & Ameronothrus bilineatus Michael & (Oribatei) & - & - & - & - & - & - & $\mathrm{x}$ \\
\hline L, C & Nanorchestes amphibius Tops \& $\mathrm{Tr}$. & (Nanorchestidae) & $\mathrm{x}$ & - & $\mathrm{x}$ & $\mathrm{x}$ & - & - & $\mathrm{x}$ \\
\hline C & Bdella septemtrionalis Atyeo \& Tuxen & (Bdellidae) & - & - & - & $\mathrm{x}$ & - & - & $\mathrm{x}$ \\
\hline $\mathrm{L}$ & Abrolophus rubipes Trou. & (Erythraeidae) & $\mathrm{x}$ & $\mathrm{x}$ & - & - & - & - & - \\
\hline L & Hydrogamasus sp. & (Eugamasidae) & - & - & - & - & - & $\mathrm{x}$ & $\mathrm{x}$ \\
\hline $\mathrm{C}$ & Rhombognathus setosus Lohmann & (Rhombognathidae) & $\mathrm{x}$ & - & - & $\mathrm{x}$ & - & - & $\mathrm{x}$ \\
\hline $\mathrm{C}$ & Rhombognathus notops Gosse & (Rhombognathidae) & $\mathrm{x}$ & - & - & - & - & - & - \\
\hline $\mathrm{L}$ & Agauopsis sp. & (Halacaridae) & - & - & - & - & - & - & $\mathrm{x}$ \\
\hline C & Halacarellus basteri Johnston & (Halacaridae) & $\mathrm{x}$ & - & - & - & - & - & - \\
\hline \multicolumn{10}{|c|}{ Insecta } \\
\hline $\mathrm{C}$ & Anurida maritima Guerin & (Neanuridae) & -. & - & $\mathrm{x}$ & - & $\mathrm{x}$ & $x$ & $\mathrm{x}$ \\
\hline $\mathrm{C}$ & Hypogastrura viatica Tullberg & (Hypogastruridae) & $\mathrm{x}$ & - & - & - & - & - & - \\
\hline $\mathrm{C}$ & Petrobius brevistylis Carpenter (juv.) & (Machilidae) & - & $\mathrm{x}$ & - & $\mathrm{x}$ & $\mathrm{x}$ & $\mathrm{x}$ & $\mathrm{x}$ \\
\hline $\mathrm{C}$ & $\begin{array}{l}\text { Telmatogeton japonicus Tokunaga } \\
=T \text { remanei Remmert }\end{array}$ & (Chironomidae) & $\mathrm{x}$ & $\mathrm{x}$ & $\mathrm{x}$ & $\mathrm{x}$ & - & - & - \\
\hline \multirow[t]{2}{*}{$\mathrm{C}$} & Halocladius variabilis Staeger & & & & & & & & \\
\hline & $=$ Trichocladius vitripennis sensu Otto & (Chironomidae) & $\mathrm{x}$ & - & - & - & $\mathrm{x}$ & $\mathrm{x}$ & $\mathrm{x}$ \\
\hline $\mathrm{L}$ & Geranomyia unicolor Haliday & (Limoniidae) & - & - & - & - & - & - & $\mathrm{x}$ \\
\hline $\mathrm{C}$ & Fucellia spp. & (Anthomyidae) & $\mathrm{x}$ & $\mathrm{x}$ & - & - & - & - & - \\
\hline C & Scatella sp. & (Ephydridae) & $\mathrm{x}$ & $\mathrm{x}$ & - & - & - & - & - \\
\hline $\mathrm{C}$ & Scatophila sp. & (Ephydridae) & $x$ & $\mathrm{x}$ & - & - & - & - & - \\
\hline
\end{tabular}

\section{Structure and modifying factors}

\section{Moisture}

The degree of moisture of the thin algal layer in the black zone is primarily determined by the littoral level and slope, wave exposure, tidal influences, amount of precipitation (rain and dew), air humidity, insolation, and water capacity of the substratum. Den Hartog (1959) and Nienhuis (1969) investigated the influence of substratum water capacity on the zonation of littoral plants and found that the upper limit of eulittoral zones is higher on soft than on hard rocks. In the present paper, the influence of moisture was determined by looking at the effect of littoral slope and rain.

Fig. 2 shows the density of dominant species at 2 adjacent sites in the Kiel Canal (Landwehr) with 10 or $45^{\circ}$ angle; these are Telmatogeton japonicus, Hyadesia fusca and Mniobia symbiotica. The SL-line (sea level) characterizes the margin between more or less desiccation-tolerant species (Kronberg 1983). The higher moisture at the flatter site leads to a more diverse fauna, traceable to intruders such as Monhystera parva, $M$. disjuncta, Chromadora macrolaima, Anaplectus sp., Dichromadora cephalata, Nitocra
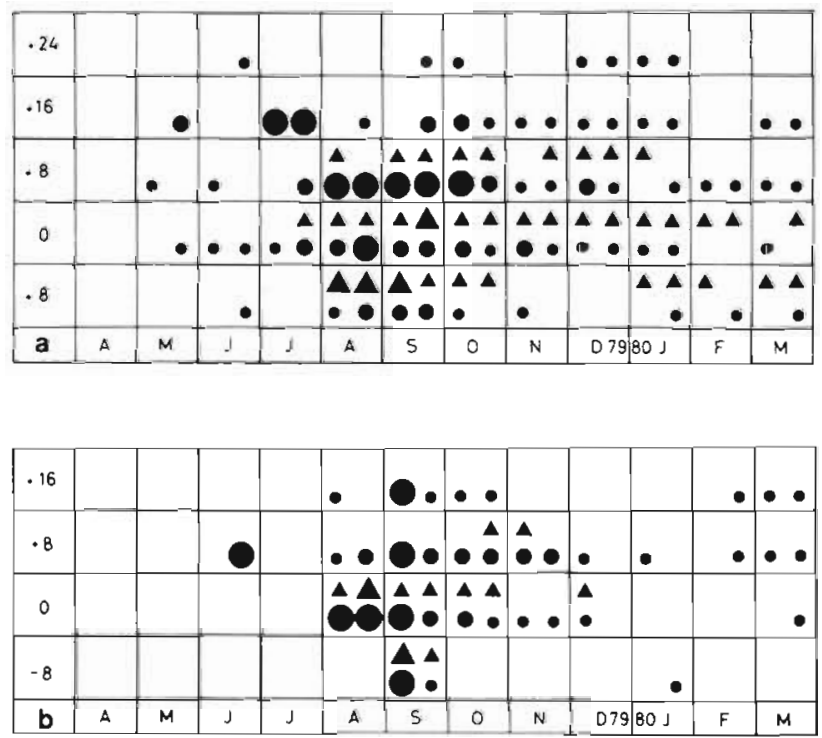

Fig. 2. Density of foundation species in the black zone of Kiel Canal (Landwehr, 8.2\%) with a slope of (a) $10^{\circ}$ (b) $45^{\circ}$. 0 : sea level (SL); $-8: 8 \mathrm{~cm}$ below SL; $+8 /+16 /+24: 8 / 16 / 24 \mathrm{~cm}$ above SL. Density of Hyadesia fusca: large circle: $\geqslant 50$ ind. $10 \mathrm{~cm}^{-2}$; medium sized circle: $\geqslant 10$ ind. $10 \mathrm{~cm}^{-2}$; small circle $<10$ ind $10 \mathrm{~cm}^{-2}$. Density of Telmatogeton japonicus instars large triangle: $\geqslant 10$ ind. $10 \mathrm{~cm}^{-2}$; small triangle: $<10$ ind. $10 \mathrm{~cm}^{-2}$ 
typica and Cytherura gibba. Moreover, there are obvious differences in the abundance of the common species $H$. fusca and $T$. japonicus: the flatter shore is inhabited more densely and for a longer seasonal period. The aquatic $M$. symbiotica is absent at the dryer $45^{\circ}$ shore.

Rainfall brings freshwater and moisture to the black zone. Faunal composition was compared at 2 adjacent sites in Friedrichsort (Kiel Bight), one protected from rain by a bridge, the other exposed to rain. As shown in Fig. 3 no differences in the abundances of the dominant

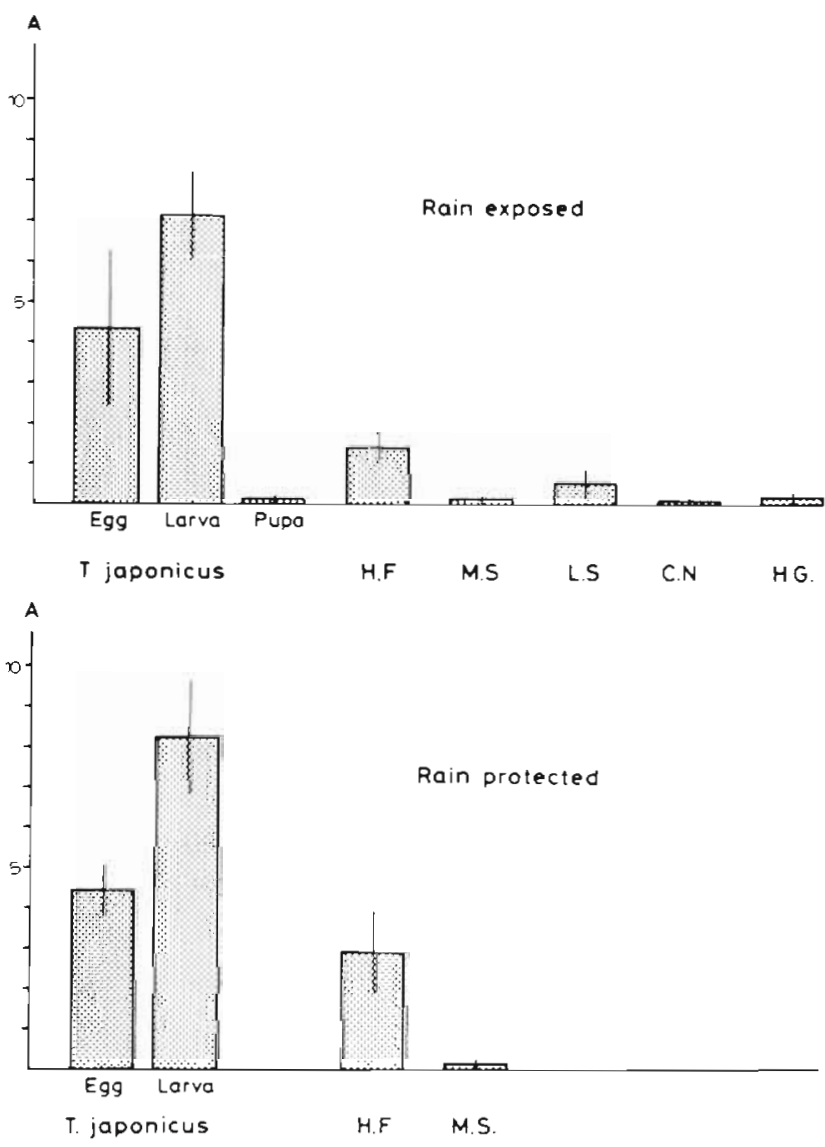

Fig. 3. Abundance of the fauna in the black zone of Kiel Bight (Friedrichsort) at a rain-exposed and rain-protected station. H.F.: Hyadesia fusca; M.S.: Mniobia symbiotica; L.S.: Littorina saxatilis; C.N.: Chromadora nudicapitata; H.G. Harpacticus gracilis; $\mathrm{A}$ : abundance (ind $10 \mathrm{~cm}^{-2}$ ); bar: $\pm 1 \mathrm{SE}$

species Hyadesia fusca, Telmatogeton japonicus and Mniobia symbiotica ( $U$-test, $\alpha=0.05$ ) could be detected, but the moister algal layer was inhabited by several eulittoral intruders not found at the rainprotected site: Littorina saxatilis, Chromadora nudicapitata and Harpacticus gracilis. Thus humidity, more than freshwater influenced by rainfall, changed the faunal composition in the black zone.
In conclusion: dryer living conditions narrow the species inventory, lower faunal diversity, and enhance the abundance of the remaining species.

\section{Salinity}

Salinity of the interstitial water in the black zone is influenced by contact with seawater, rain and evaporation. The Kiel Canal shows a more or less continuous decrease in salinity from 12 to $3 \%$ and hence is an ideal site for studying the influence of salinity on faunal structures. Fig. 4 shows the abundance values of

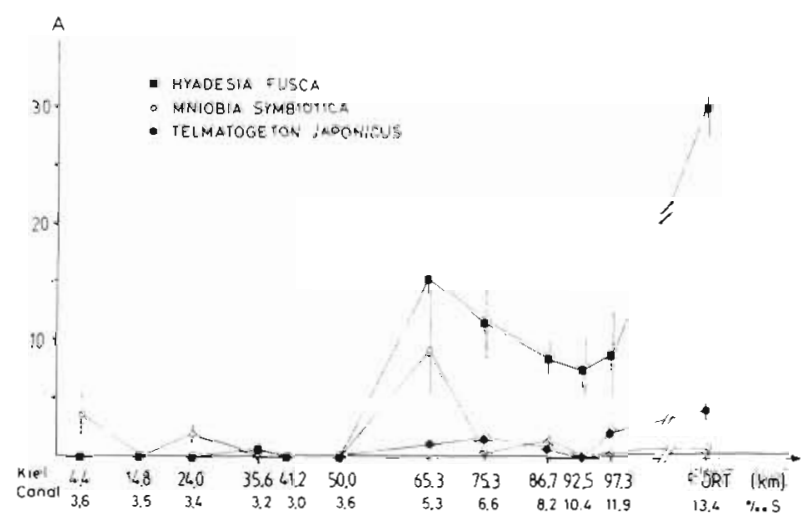

Fig. 4. Abundance of foundation species (Hyadesia fusca, Mniobia symbiotica, Telmatogeton japonicus instars) in the black zone along Kiel Canal and Kiel Bight. F.'ORT. Friedrichsort; km: canal distances, from Brunsbüttel to Kiel; S: salinity; $A$ : abundance (ind. $10 \mathrm{~cm}^{-2}$ ); bar: $\pm 1 \mathrm{SE}$

dominant species: the eastern marine brackish part of Kiel Canal ( 11.9 to $5.3 \%$ ) is densely populated with Hyadesia fusca and Telmatogeton japonicus instars. These species are nearly absent in the western limnetic brackish part (3.6\% and lower); Mniobia symbiotica and the nematode genera Aphelenchoides and Plectus appear only irregularly. The density of $H$. fusca and $T$ japonicus instars is significantly correlated with salinity ( $\alpha=0.05$, Rank-Spearman), though in $T$. japonicus this influence is intermixed with the initial outspread of the midge in the Baltic Sea (Kronberg 1986). In 1982, T. japonicus instars were also found near Brunsbüttel (3.6\%), and near Helgoland (30 to $35 \%$ ); the salinity tolerance would thus appear greater than estimated in the first survey. In the laboratory the salinity tolerance of $H$. fusca was 0.05 to $40 \%$ (Ganning 1970).

For comparison, poly- and euhaline stations near Kristineberg (Sweden), Herdla (Norway) and Helgoland were investigated. Here Echiniscoides sigismundi is an additional member of the faunal inventory and an exceptional occurrence of Littorina neritoides was reported (Lewis \& Tambs-Lyche 1962, Ziegelmeier 1966). 
The influence of salinity on the faunal structure in the black zone can be summed up as follows: the species inventory is displaced, diversity remains nearly constant, and the abundance of species changes.

Temperature, light, and wave exposure

These abiotic factors further influence faunal composition in the black zone. The higher the littoral level, the greater is the importance of air temperature compared with water temperature; this results in more daily and seasonal variation than occurs in the lower littoral zones.

Light reflection from rocks elevates temperature in the immediate vicinity of the black zone: $25^{\circ} \mathrm{C}$ air and $23^{\circ} \mathrm{C}$ water temperature (August 1982, Bülk) resulted in $35^{\circ} \mathrm{C}$ above the stones. Wave spray cools the air quickly to $29^{\circ} \mathrm{C}$, and not only thermal causes but also mechanical stress to the organisms.

Extremely low temperatures result in mechanical damage from floating ice; this may destroy the whole environment and result in a bare zone, as in the Scandinavian area (Lewis 1964). Frost resistance may be a function of cell physiology as in Mniobia symbiotica, which survived experimental freezing at $-18^{\circ} \mathrm{C}$, or of behaviours as in Littorina saxatilis which retreats to the ice-free eulittoral, or as in Telmatogeton japonicus which survives in tubes built in small crevices.

Along exposed shores, the upper limit of littoral communities is displaced landwards; biological zonation thus shows a greater discrepancy to hydrographical zonation (Lewis 1964). The extension of the black zone serves as an indicator for the degree of wave exposure (Ballantine 1961, Lewis 1964). The Lichina pygmaea and Verrucaria maura associations prefer exposed shores, while cyanophytes prefer sheltered shores. The resulting changes are followed by altered faunal settlement as described below in 'Biotic factors'.

\section{Eutrophication}

The influence of eutrophication on the structure of the fauna in the black zone was investigated in Bülk (northwestern exit of Kiel Bight) where domestic sewage from Kiel discharges into the Baltic Sea. The sewage is composed of organic materials, i. e. materials with high content of P, N and Si (Horstmann 1971, Anger 1975), which are less dense than seawater, and which thus drift at the surface. During easterly winds the sewage extends along the beach in a northwesterly direction (Horstmann 1971), resulting in different influences for each of the investigated stations. Eight (in 1981) or 7 (in 1982) breakwaters served as sample stations. Differ- ences in the composition of the overgrowth did not reveal any significant influence on the faunal structure (Rank-Spearman correlation; Kronberg 1983).

Again, the animals most abundant were Hyadesia fusca, Telmatogeton japonicus, Mniobia symbiotica, and occasionally Hypogastrura viatica. These species have the main impact on the living density. Fig. 5 shows the living density $\left(10 \mathrm{~cm}^{-2}\right)$ at 8 or 7 stations in Bülk in

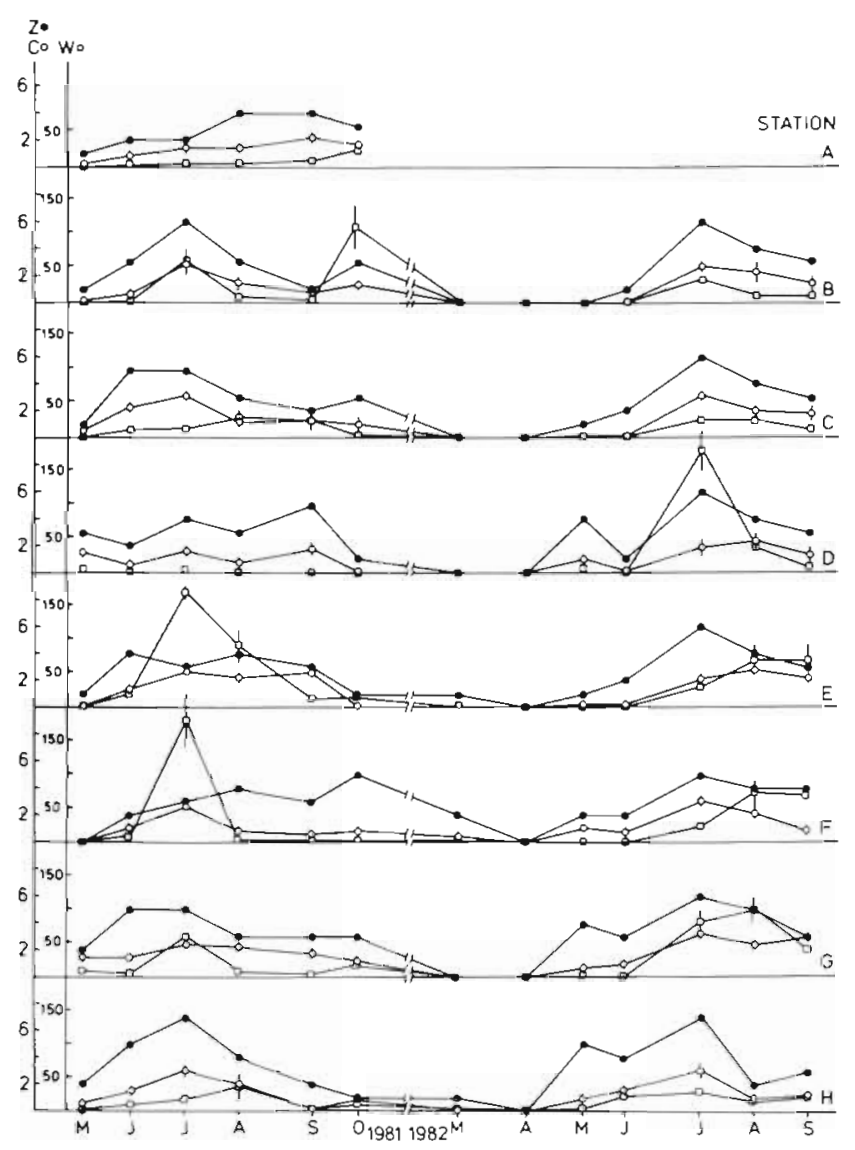

Fig. 5. Species number $(Z)$, species density $(C)$ and living density ( $W$ ) per $10 \mathrm{~cm}^{2}$ in the black zone of differently eutrophicated adjacent breakwaters in Bülk (Stns $A$ to $\mathrm{H}_{\text {, Kiel }}$ Bight; bar: $\pm 1 \mathrm{SE})$

1981 and 1982, respectively. The black zone is most densely inhabited from June to September. In the cold season, almost no fauna at all was recorded, and a quantitative analysis was not possible. Remarkable is the repeated occurrence of sudden increases in living density, due to the reproduction of $H$. fusca and $M$. symbiotica. Population dynamics of $M$. symbiotica do not show a high synchrony between stations, in contrast to the situation for $H$. fusca and $T$. japonicus instars which are most abundant in July and August. In addition to these typical phytal organisms, aquatic intruders are present, such as Nematoda, Copepoda-Harpac- 
ticoidea, Ostracoda, Acarina (Rhombognathidae), Littorina saxatilis, Mytilus edulis (juvenile) and terrestrial intruders such as Abrolophus rubipes, Ameronothrus spp. and Nanorchestes amphibius. However, their density is not important. An exception is Hypogastrura viatica (Collembola) which may reach such high densities (200 ind. $10 \mathrm{~cm}^{-2}$ in July 1982) that the black zone appears blue. $H$. viatica is saprophagous and known to appear at sewage filters. Species density is more uniform and never greatly exceeded 3 species $10 \mathrm{~cm}^{-2}$, which concurs with the number of dominant species. Total number of species per month reached 8 in summer (Fig. 5).

The eutrophication effect of sewage cannot be quantified but can be ranked and thus correlated to diversity, species density, living density, and abundance of species (Rank-Spearman correlation; Kronberg 1983). In 1981 no significant correlation could be found; in 1982, only singular correlations could be detected: species density and living density decreased in June 1982 with increased eutrophication, due to the preference of Mniobia symbiotica for cleaner breakwaters. The same behaviour was observed in Nematoda in July 1982. Hypogastrura viatica was found more often in the neighbourhood of the outfall (July and August 1982) since it feeds on decomposing organic materials. No further correlations could be detected and, as the correlation appears only temporarily the dependency of faunal structure on eutrophication appears small or hidden by other microclimatic factors.

The abundance of foundation species (Hyadesia fusca, Telmatogeton japonicus, Mniobia symbiotica) at different stations showed significant differences (Kruskal-Wallis-Test: Kronberg 1983). Population dynamics were thus not uniform at differently eutrophicated breakwaters. Only during scarce settlement were no differences detectable. Quantitative similarity (Kulczynski index) is slight (Fig. 6). Identity of community structure $\left(I_{\mathrm{k}} \geqslant 0.80 ;\right.$ Kronberg 1987) was achieved only once in 1981 and 1982 at 2 adjacent stations. In $29 \%$ of comparisons, the index was less than 0.1 . Faunal structure at adjacent breakwaters revealed considerable differences

Qualitative similarity between stations was never less than $50 \%$; in summer it often reached values greater than $I_{s}=0.85$, i.e. identity according to the accuracy of the species minimal area. Qualitative similarity thus far exceeded quantitative (Fig. 7). The presence of foundation species reached values of nearly $100 \%$ in summer (Fig. 8), diminishing towards winter.

Sewage in Bülk caused no detectable disturbance to the faund in the black zone. Quantitative parameters reacted appreciably to regional and seasonal changes, but no particular microclimatic causality was found. Compared to the unstable abundance values, faunal

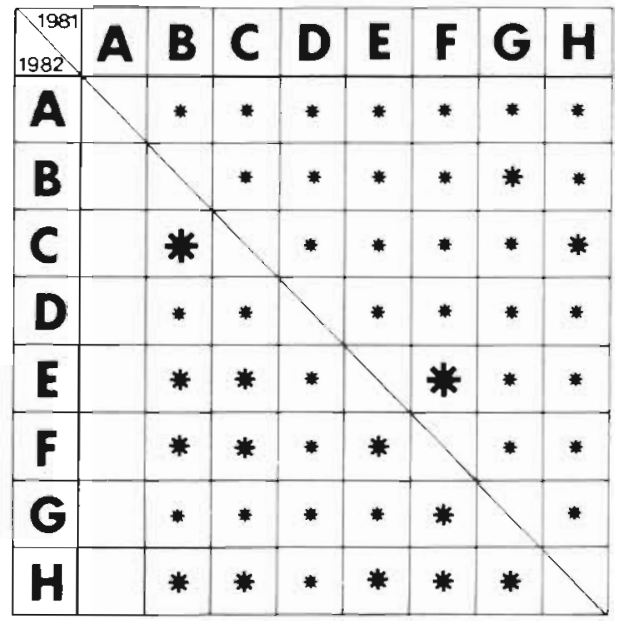

Fig. 6. Quantitative similarity (Kulczynski-Index, $I_{\mathrm{k}}$ ) of the fauna in the black zone at differently eutrophicated adjacent breakwaters during densest settlement in July 1981 and July 1982 (Stns A to H, Bülk, Kiel Bight; $I_{\mathrm{k}}$ : large star 1.0 to 0.86 (identity); medium sized star: 0.85 to 0.41 ; small star: 0.40 to 0 )

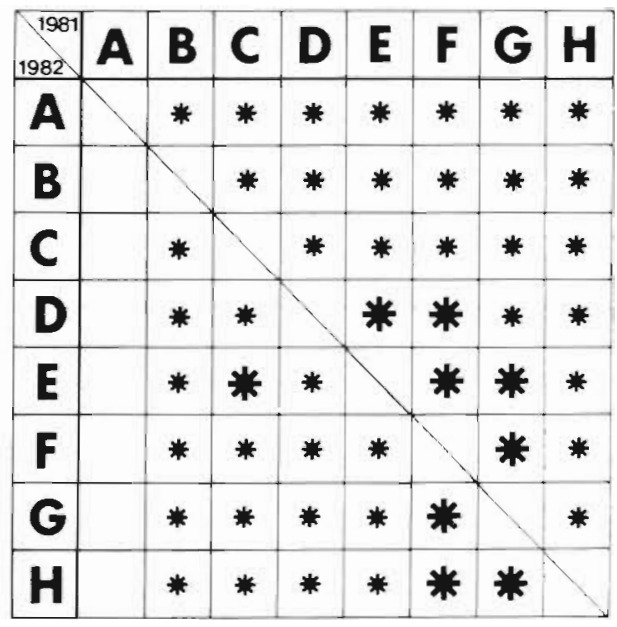

Fig. 7. Qualitative similarity (Sørensen-Index, $I_{s}$ ) of the fauna in the black zone at differentiy eutrophicated adjacent breakwaters during densest settlement in July 1981 and July 1982 (Stns A to $\mathrm{H}$, Bülk, Kiel Bight; $I_{\mathrm{s}}$ : large star: 1.0 to 0.81 (identity); medium sized star: 0.80 to 0.41 ; small star: 0.40 to 0 )

composition remained nearly unchanged - even extreme density variation did not lead to a collapse of the community. The diversity-stability-hypothesis (MacArthur 1955), which predicts low stability in communities of low diversity, is not supported in the black zone.

\section{Biotic factors}

Besides abiotic factors, biotic factors such as plant substratum character may control the settlement of the fauna in the black zone. To compare the faunal composition in different associations of the black zone, 


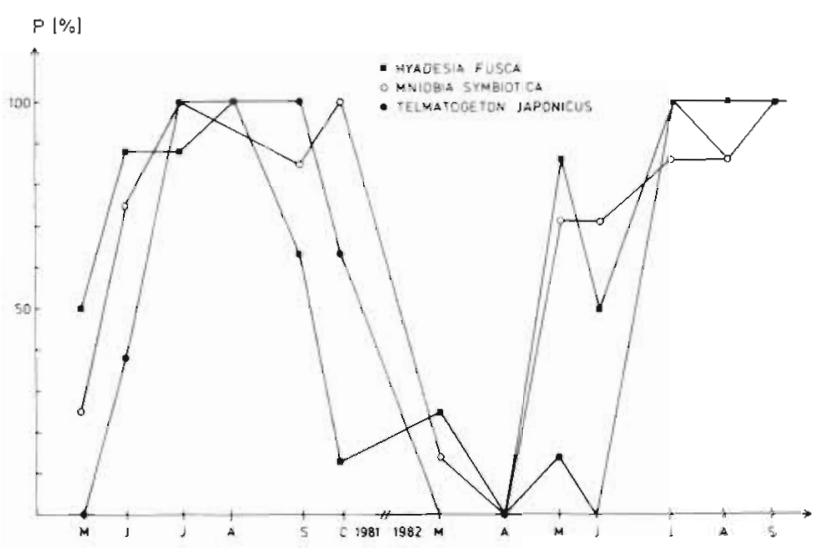

Fig. 8. Presence $(P)$ of foundation species (Hyadesia fusca, Mniobia symbiotica, Telmatogeton japonicus instars) in the black zone of differently eutrophicated adjacent breakwaters in Bülk (Stns A to H: 1981; Stns B to H: 1982)

Lichina pygmaea (shrub-like lichen) and Cyanophyta in different climates were analysed. As the samples were not of the same size, rarefaction diversity (Sanders 1968) was chosen to compare the fauna (Fig. 9). Lichina and Cyanophyta associations show a gradual approximation to saturation level because there were only 2 or 3 dominant species but a few rare species; species evenness in both environments is therefore low. Species richness, designated by height of the curve, is a little higher in the Lichina association than in blue-green algae.

\section{Adaptation}

Since the extremely variable living conditions proved exacting on fauna adaptation, different responses from terrestrial and aquatic intruders were to be expected.

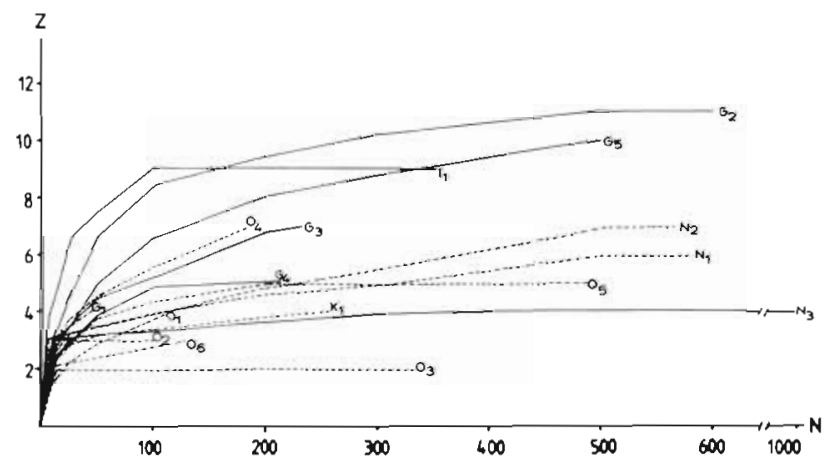

Fig. 9. Rarefaction diversity of the fauna in Lichina pygmaea associations (-) and Cyanophyta associations (--.-) in the black zone of different climatic regions. $Z$ : number of species; $N$ : number of individuals; $\mathrm{O}_{1}$ to $\mathrm{O}_{6}$ : eastern coastline of Schleswig-Holstein (F. R. Germany); $K_{1}$ : Kiel Canal (F. R. Germany); $N_{1}$ to $N_{3}$ : Herdla (Norway); $G_{1}$ to $G_{5}$ : Penzance (Cornwall, UK); $\mathrm{I}_{1}$. Sherkin Island (Ireland)
Protection

Protection was primarily directed against abiotic factors such as desiccation, submersion, exposure and heat; predators were not important.

The tubes of Telmatogeton japonicus instars, where pupation subsequently takes place, are built in small crevices and represent protective adaptations of foundation species in the black zone. The pupa bears cuticular structures (respiratory horns, terminal abdominal disk) which close these tubes.

Physiological adaptations were more important than morphological patterns. Tardigrada, Nematoda and Rotatoria are predisposed to tolerate an extremely variable environment by their ability to survive through anhydrobiosis; this ability is best developed in moss organisms. In the quiescent stage, these Tardigrada are able to withstand several days or even months of desiccation or other extreme abiotic factors such as cold $\left(-271.9^{\circ} \mathrm{C}\right.$ for $\left.20 \mathrm{mo}\right)$ or heat $\left(100{ }^{\circ} \mathrm{C}\right.$ for $\left.6 \mathrm{~h}\right), \mathrm{O}_{2}$ absence, vacuum, $\mathrm{X}$-rays and radium radiation (Marcus 1928). No measurable metabolism occurs (Keilin 1959, Crowe \& Madin 1974, Kronberg 1983 for Echiniscoides sigismundi). Anhydrobiosis is life in the absence of water': free water in the cells is subsituted by glycerol (Crowe \& Madin 1974). Trehalose serves as a carbohydrate store (Crowe \& Madin 1974, Womersley \& Smith 1981). Mniobia symbiotica survived freezing at $-18^{\circ} \mathrm{C}$ in the contracted stage for several months.

The shell of gastropods presents a predisposition for surviving in temporarily drying environments. The influence of different shell globosity and sculpture on littoral level was investigated by Vermeij (1973). The colour of snails may serve as a protection from predators such as seabirds and crustaceans (Heller 1975). Littorinids close their shell using their operculum, such that isolating air between body and substratum prevents heat conduction from the substratum. Also in littorinids, changes in energy metabolism occur during air exposure: they change to a low anaerobic homeostasis e. g. $41 \%$ of active metabolism (heat dissipation) in Littorina saxatilis, and $25 \%$ in L. neritoides (Kronberg 1983).

Aquatic and terrestrial intruders - such as Rhombognathidae, Ostracoda, Copepoda-Harpacticoidea, Oribatei and Collembola - remain in moist or dry refuges respectively. Many terrestrial species wear a hydrophobic integument (Cheng 1976).

\section{Locomotion}

Mobility in the black zone includes the possibility of retreating into crevices, but also a risk of being washed out of the overgrowth by waves. The foundation 
species thus tend to a haptic behaviour with suction tubes, mucous secretion, or claws. Hyadesia fusca possesses a third claw between the lateral claws with a long muscular connecting piece. This claw serves as an elastic anchor. Instars of Telmatogeton japonicus are unable to swim in open water, but crawl by attaching with their mandibles and anterior and posterior parapods. When disturbed, they discharge a large amount of adhesive saliva to attach themselves to the substrate or to build a girdle around the thorax. The rotifer Mniobia symbiotica also avoids swimming and moves like a leech. The foot contains glands secreting agglutinant to adhere to algal thalli.

Littorinids use their suction foot as long as they are moistened: they retract into their shell during desiccation. The shell is then anchored by dried mucus. Many intruding species, conversely, show high vagility, often linked with the ability to jump, as in the case of Ligia spp., Talitrida, Petrobius maritimus, Collembola and Nanorchestes amphibius. This enables them to retreat into crevices

\section{Reproduction and development}

Adaptation of adults to extreme conditions ensures survival of the population only if the delicate development stages such as the ovular, juvenile and desquamation stages are protected too. In the black zone, the sensitivity of these stages is often reduced by shortening their duration; ovoviviparity and a short pupation stage make this possible.

Hyadesia fusca is ovoviviparous, and juveniles appear in July (black zone, Baltic Sea) or June (rockpools, Great Britain; Ganning 1970). The imagino of Telmatogeton japonicus is short-lived (24 to $36 \mathrm{~h} ; 20 \mathrm{~h}$, Wirth 1947); the female abdomen containing 200 to 300 eggs which are laid separately into the moist overgrowth. Instars moult 4 times until pupation. The 4 th instar shows a fully developed genital tract, even eggs and sperm are differentiated. Imaginal disks show the shape of legs and the terminal abdominal disk is recognizable. Pupation takes place in the web tube, obviously initiated by dry conditions; in wet turf no pupae were found. Under dry conditions, significantly smaller instars revealed maturity (Kronberg 1983). Quiescence during pupation therefore only serves the sclerotisation of imaginal organs already formed.

Mniobia symbiotica propagates parthenogenesis which leads to a high variability between populations. Its occurence in fresh water and marine habitats is possibly an indicator of species separation (Otto 1936). Unlike some moss-dwelling species, Echiniscoides sigismundi does not lay eggs in the exuvium for protection (Kromberg 1983).
Among the littorinids, ovoviviparity occurs in Littorina saxatilis. The higher-zoned L. neritoides is oviparous like eulittoral Littorina species. Even within the $L$. saxatilis complex there are species which lay eggs, for example L. arcana (Hannaford-Ellis 1978). Therefore no correlation exists between tidal level and the mode of reproduction of littorinids - even 'reproductive effort' sensu Hughes \& Roberts (1980) is independent of littoral zonation.

\section{Ingestion}

Food availability in the black zone includes epilithic blue-green and green algae, lichens and detritus. Cyanophytes were identified by fluorescent microscopy and were found in the stomach of all foundation species and of some intruders: Telmatogeton japonicus instars, Hyadesia fusca, Mniobia symbiotica, Echiniscoides sigismundi, Littorina saxatilis, L. neritoides, Anurida maritima, Rhombognathus setosus, $R$. notops, Campecopea hirsuta, Ligia oceanica (juv.) (Kronberg 1983). A massive number of $L$. saxatilis may destroy the environment in the lower regions as observed at Bülk in August-September 1981 and 1982. Predators are found only as intruders from neighbouring environments: small arthropods such as A. maritima, chironomid instars and Nanorchestes amphibius are prey for mites such as Neomolgus litoralis and Bdella longicornis (Alberti 1973). T. japonicus adults are eaten by some flies (Chopodidae, Anthomyiidae; Wirth 1947). Littorina spp. are prey for seabirds and crabs (Raffaelli 1978), for blenniid fishes, for predatory snails (Nucella sp.) and even rats (Pettitt 1975). Moreover, they are hosts for parasitical trematodes (family Microphallidae), which may lead to oversized growth by sterilization (McManus \& James 1975, Elner \& Raffaelli 1980, Irwin \& Irwin 1980).

Thus the foodweb in the black zone is very simple, consisting of some phytophagous, seldom omnivorsaprophagous, species which are occasionally consumed by predatory intruders.

\section{CONCLUSIONS}

The black zone in wave spray regions of rocky shores is an extremely variable environment with cosmopolitan characteristics. Moisture, salinity, and temperature fluctuate within a wide range. In addition to lichens (Verrucaria maura, Lichina pygmaea), blue-green algae create the blackish colour. As littoral cyanophytes are phylogenetically rather old, the environment appears to represent ancient conditions.

Faunal composition. The fauna consists of thalasso- 
gen (Echiniscoides, Littorina, Lasaea, Campecopea) and limnio-terrestrial genera (Hyadesia, Telmatogeton, Mniobia) and corresponds with the topographic position between marine littoral and terrestrial supralittoral. An obvious relationship exists to the fauna in mosses.

Diversity is very low: there are no coenobiont and only 3 to 5 coenophile species. Most animals are intruders from neighbouring environments that only live or feed here temporarily. Low diversity corresponds to the low heterogeneity in the environment. Competition for crevices is strong, and in general only 1 species occupies a defined size class (length/width): Telmatogeton japonicus instars $(10 / 0.8 \mathrm{~mm})$, Hyadesia fusca $(0.5 / 0.3 \mathrm{~mm})$, Mniobia symbiotica $(0.4 / 0.05 \mathrm{~mm})$, each needing a particular crevice size.

Adaptation. Foundation species are haptic forms, most intruders are vagile and often retreat into refuges by jumping. The duration of sensitive development stages may be shortened by ovoviviparity or short pupation. The foodweb is simple; foundation species are phytophagous. Predators occur only occasionally, and come from neighbouring environments. Protection is thus more against abiotic than biotic factors. Shells, cuticular structures, and web tubes protect against desiccation, washing out, and heat. The most important adaptation lies in the ability to survive unfavourable circumstances in stages of quiescent life. Metabolism is reduced to a level which satisfies an extremely low homeostasis. Tardigrada, Rotatoria and Nematoda choose anhydrobiosis for this purpose; littorinids, anaerobiosis. This behaviour often makes further adaptations superfluous - adaptation to active terrestrial life does not take place.

Faunal structure. The influence of abiotic factors on the structure of the biocenosis can be interpreted as follows: moisture changes species composition, whereas salinity influences the density of species. Only in freshwater associations are new faunal elements added; often blue-green algae are displaced by mosses. Biotic factors are not very important: the shrublike lichen Lichina pygmaea accomodates only a few more species than cyanophytes, which is apparently due to the higher spatial heterogenity and accompanying higher crevice availability. Fauna is bound not so much to the quality of overgrowth but to the littoral level with its special moisture conditions.

Though the community shows high seasonal and regional variations in density caused by microclimatic factors, species composition remains nearly unchanged. The community is qualitatively stable, which contradicts the diversity-stability-hypothesis (MacArthur 1955). For many species in the black zone high variability is reported (Otto 1936 for Mniobia symbiotica; Kristensen \& Hallas for Echiniscoides sigismundi; Smith 1981, Janson 1985 for Littorina saxatilis). Thus it is supposed that polymorphism in low diversity and species diversity in high diversity environments ensures the resilience of communities. Artificially poor systems, such as man-made monocultures, do not show diversity in either respect and are more susceptible to external disturbance. In an unpredictable environment such as the black zone, polymorphous communities have a selective advantage over monomorphous ones (Grassle 1972). Thus the small species inventory in the black zone is not an artifact but the result of natural selection.

\section{LITERATURE CITED}

Alberti, G. (1973). Ernährungsbiologie und Spinnvermögen der Schnabelmilben (Bdellidae, Trombidiformes). Z. Morph. Tiere 76: 285-338

Anger, K. (1975). Benthos und Abwasser. Die Auswirkungen kommunaler Abwässer auf ein ufernahes Partialökosystem der westlichen Ostsee. Thesis, Christian-AlbrechtsUniversität, Kiel

Ballantine, W. J. (1961). A biologically-defined exposure scale for the comparitive description of rocky shores. Fld. Stud. 1 (3): $1-19$

Broady, P. A. (1981). Ecological and taxonomic observations on subaerial epilithic algae from Princess Elizabeth Land and McRobertson Land, Antarctica. Br. Phycol. J. 16 (3): 257-266

Cheng, L. (1976). Marine insects. North Holland Pub., Amsterdam

Crowe, J. H., Madin, K. A. (1974). Anhydrobiosis in Tardigrades and Nematodes. Trans. Am. Microsc. Soc. 93 (4): 513-524

Dayton, P. K. (1972). Towards an understanding of community resilience and the potential effects of enrichment to the benthos at McMurdo Dound, Antarctica. In: Parker, B. C. (ed.) Proc. Collq. Conserv. Prob., Allen Press, Lawrence, Kansas, p. 81-95

Den Hartog, C. (1959). The epilithic algal communities occuring along the coast of the Netherlands. Wentia 1: 1-241

Donner, J. (1965). Bestimmungsbücher zur Bodenfauna Europas 6: Ordn. Bdelloidea (Rotatoria, Rädertiere). Akademie-Verlag, Berlin

Elner, R. W., Raffaelli, D. G. (1980). Interactions between two marine snails, Littorina rudis and Littorina nigrolineata, a predator, Carcinus maenas and a parasit Microphallus similis. J. exp. mar. Biol. Ecol. 43 (2) : 151-160

Fletcher, A. (1973). The ecology of maritime (supralittoral) lichens on some rocky shores of Anglesey. Lichenologist 5: $401-422$

Ganning, B. (1970). Population dynamics and salinity tolerance of Hyadesia fusca (Acarina, Sarcoptiformes) from brackish water rockpools, with notes on the microenvironment inside Enteromorpha tubes. Oecologia (Berl.) 5; $127-137$

Grassle, J. F. (1972). Species diversity, genetic variability and environmental uncertainty. In: Battaglia, B. (ed.); 5th European Mar. Biol. Symp. Piccin, Padua, p. 19-26

Green, J. (1950). Habits of the marine tardigrade Echiniscoides sigismundi. Nature, Lond. 166: 153-154

Hannaford-Ellis, C. J. (1978). Littorina arcana sp. nov.: a new species of winkle (Gastropoda: Prosobranchia: Littorinidae). J. Conch. Lond. 29: 304

Hedgpeth, J. W. (1957). Treatise on marine ecology and 
paleoecology: 1. Ecology. GeologicalSocietyof America, New York, Memoir 67

Heller, J. (1975). Visual selection of shell color in two littoral prosobranchs. Zool. J. Linn. Soc. 56 (2): 153-170

Horstrnann, U. (1971). Über den Einfluß von häuslichem Abwasser auf das Plankton der Kieler Bucht. Thesis, Christian-Albrechts-Universität, Kiel

Hughes, R. N., Roberts, D. J. (1980). Reproductive effort of winkles (Littorina spp.) with contrasted methods of reproduction. Oecologia (Berl.) 47 (1): 130-136

Hurlbert, S. H. (1971). The nonconcept of species diversity: a critique and alternative parameters. Ecology 52: 577-586

Irwin, S. W. Irwin, B C. (1980). Distribution of metacercariae of Maritema arenaria (Digenea: Miccrophallidae) in the barnacle Balanus balanoides at 3 sites on the east coast of Northern Ireland, U.K. J. mar. biol. Ass. U. K. 60 (4): 959-962

Janson, K. (1985). Polymorphism, causes and evolutionary consequences in a marine prosobranch species, Littorina saxatilis. Thesis, University of Goteborg

Keilin, D. (1959). The problem of anabiosis or latent life: history and current concept. Proc. R. Soc. Lond. B 150: 149-191

Kristensen, R. M., Hallas, T. E. (1980). The tidal genus Echiniscoides and its variability, with erection of Echiniscoididae fam. n. (Tardigrada). Zool. Scr 9: 113-127

Kronberg, I. (1983). Ökologie der Schwarzen Zone im marinen Felslitoral: Monographie eines extremen Lebensraumes. Thesis, Christian-Albrechts-Universität, Kiel

Kronberg, I. (1986). Riesenchromosomen und Artareal einer baltischen Telmatogeton-Art (Diptera: Chironomidae: Telmatogetoninae). Z. zool. Syst. Evolutionsforsch. 24 (3): 190-197

Kronberg, I. (1987). The accuracy of species- und abundance minimal areas determined by similarity area curves. Mar. Biol. 96 (4) : 555-561

Laporte, L. F. (1968). Ancient environments. In: McAlester, A. L. (ed.) Foundation of Earth Science Series. Prentice-Hall Inc., New Jersey

Lewis, J. R. (1964). The ecology of rocky shores. The English University Press, London

Lewis, J. R., Tambs-Lyche, H. (1962). Littorina neritoides in Scandinavi. Sarsia 7: 7-10

Lindstedt, A. (1943). Die Flora der marinen Cyanophyceen der Schwedischen Westküste. Thesis, University of Lund

Little, M. G. (1973). The zonation of supralittoral blue-green algae. Br Phycol. J. 8 (1): $47-50$

Marcus, E. (1927). Zur Anatomie und Ökologie mariner Tardigraden. Zool. Jb. Syst. 53: 487-558

Marcus, E. (1928). 12. Spinnentiere oder Arachnoidea, 4. Bärtierchen (Tardigrada). In: Dahl, F. (ed.) Die Tierwelt Deutschland und der angrenzenden Meeresteile nach ihren Merkmalen und nach ihrer Lebensweise. Verlag Gustav Fischer, Jena

MacArthur, R. H. (1955). Fluctuations of animal populations and a measure of community stability. Ecology 36: 533-536

McKirdy, D., Schmidt, P. McGinty-Baily, M. (1976). Interstitielle Fauna von Galapagos 16: Tardigrada. Mikrofauna des Meeresbodens 58: 409-449

McManus, D. P., James, B. L. (1975). Anaerobic glucose metabolism in the digestive gland of Littorina saxatilis rudis (Maton) and in the daughter sporocysts of Microphallus similis (Jäg.) (Digenea: Microphallidae). Comp. Biochem. Physiol. 51B: 293-297

Morgan, C. I., King, P. E. (1976). British Tardigrada. Synopsis of British fauna (new series) 9. Academic Press, London
Nienhuis, P. H. (1969). The significance of the substratum for the intertidal algal growth on artificial rocky shore of the Netherlands. Int. Revue ges. Hydrobiol. 54 (2): 207-215

Nordsieck, F. (1969). Die europäischen Meeresmuscheln. Gustav Fischer Verlag, Stuttgart

Otto, G. (1936). Die Fauna der Enteromorpha-Zone in der Kieler Bucht. Kieler Meeresforsch. 1: 1-48

Pettitt, C. W. (1975). A review of the predators of Littorina, especially those of Littorina saxatilis (Olivi) (Gastropoda: Prosobranchia). J. Conch. 28: 343-357

Raffaelli, D. G. (1978). The relationship between shell thickness and habitat characteristics of the intertidal snail Liuttorina rudis Maton. J. mollusc. Stud. 44 (2): 166-170

Remane, A., Schlieper, C. (1958). Die Biologie des Brackwassers. In: Thienemann, A. (ed.) Die Binnengewässer 22, E. Schweizerbart'sche Verlagsbuchhandlung, Stuttgart

Remane, J. (1979). The beginnings of life on earth. Bull. Soc. Neuchatel. Sci. Nat. 102 (0): 149-166

Sanders, H. L. (1968). Marine benthic diversity: a comparative study. Am. Nat. 102 (925): 243-282

Schulte, G. (1977). Die Bindung von Landarthropoden an das Felslitoral der Meere und ihre Ursachen. Habilitationsschrift, Christian-Albrechts-Universität, Kiel

Schuster, R. (1962). Das marine Litoral als Lebensraum terrestrischer Kleinarthropoden. Int. Revue ges. Hydrobiol. 47 : $359-412$

Smith, J. E. (1981). The natural history and taxonomy of shell variation in the periwinkles Littorina saxatilis and Littorina rudis. J. mar. biol. Ass. U. K. 61 (1): 215-242

Southward, A. J. (1958). The zonation of plants and animals on rocky sea shores. Biol. Rev. 33: 137-177

Stephenson, T A., Stephenson, A. (1972). Life between tidemarks on rocky shores. W. H. Freeman and Co., San Francisco

Thienemann, A. (1939). Grundzüge einer allgemeinen Ökologie. Arch. Hydrobiol. 35: 267-285

Umezaki, I. (1961). The marine blue algae of Japan. Mem. Coll. Agric. Kyoto Univ. 83: 1-1.49

Vermeij, G. J. (1973). Morphological patterns in high intertidal gastropods: Adaptive strategies and their limitations. Mar. Biol. 20: 319-346

Weinberg, S. (1978). The minimal area problem in invertebrate communities of mediterranean rocky substrata. Mar. Biol. 49: 33-40

Wieser, W. (1959). Zur Ökologie mariner Algen mit besonderer Berücksichtigung des Mittelmeeres. Int. Revue ges. Hydrobiol. 44: 137-180

Wirth, W. W. (1947). A review of the genus Telmatogeton Schiner, with descriptions of three new Hawaiian species (Diptera, Tendipedidae). Proc. Hawn. Ent. Soc. 13 (1) 143-191

Womersley, H. B. S., Edmonds, S. J. (1952). Marine coastal zonation in southern Australia in relation to general schemes of classification. J. Ecol. 40: 84-90

Womersley, C., Smith, L. (1981). Anhydrobiosis in nematodes: 1. Role of glycerol myo-inositol and trehalose during desiccation. Comp. Biochem. Physiol. (B) Comp. Biochem. 70 (3): 579-586

Woodward, S P. (1851). A manual of the Mollusca; or rudimentary treatise of recent and fossil shells. John Weale, London

Ziegelmeier, E. (1966). Die Schnecken (Gastropoda, Prosobranchia) der deutschen Meeresgebiete und brackigen Küstengewässer. Helgoländer wiss. Meeresunters. 13: $1-61$ 